\title{
Espejos y no biombos
}

\section{Montserrat Palmer Trías termina su período como Directora de Ediciones ARQ.}

Después de años de dirigir nuestras Ediciones ARQ y con la misma vitalidad que siempre la ha caracterizado, hoy Montserrat Palmer nos deja, siempre dispuesta a enfrentar nuevos proyectos.

Hace casi 30 años iniciaba el proyecto que hoy entrega como legado. Y lo hacía escribiendo una editorial en el lenguaje franco y directo que la caracteriza. Un lenguaje que da cuenta de un modo de pensar, cuya profundidad se expresa sin hermetismo, al alcance de todos.

Un lenguaje que se percibe en su obra de arquitectura y diseño de objetos, la cual es sin duda importante, lo demuestra la monografía que se acaba de publicar.

Lenguaje que también le permitió una importante labor académica, que culminó al ser nombrada Decano de la Facultad de Arquitectura, cargo que ejerció entre los años 2000 y 2003.

Pero sin duda su más importante obra como arquitecto y académica son las Ediciones ARQ.

En una época en que los proyectos editoriales de arquitectura eran difíciles, Montserrat quiso darle a la publicación de la revista ARQ continuidad y peso específico. Lo consiguió tan bien que unos años después ARQ fue la primera revista en castellano en ser acreditada con la categoría ISI (y una de las 11 en el mundo de ese instante referidas a arquitectura). Junto con eso, con una energía envidiable, comenzó a editar libros, de una calidad superior a muchas grandes editoriales y en una cantidad increíble para nuestro sistema de recursos.

El secreto de todo está probablemente en la editorial mencionada, que escribió para el primer número de la revista ARQ bajo su dirección.

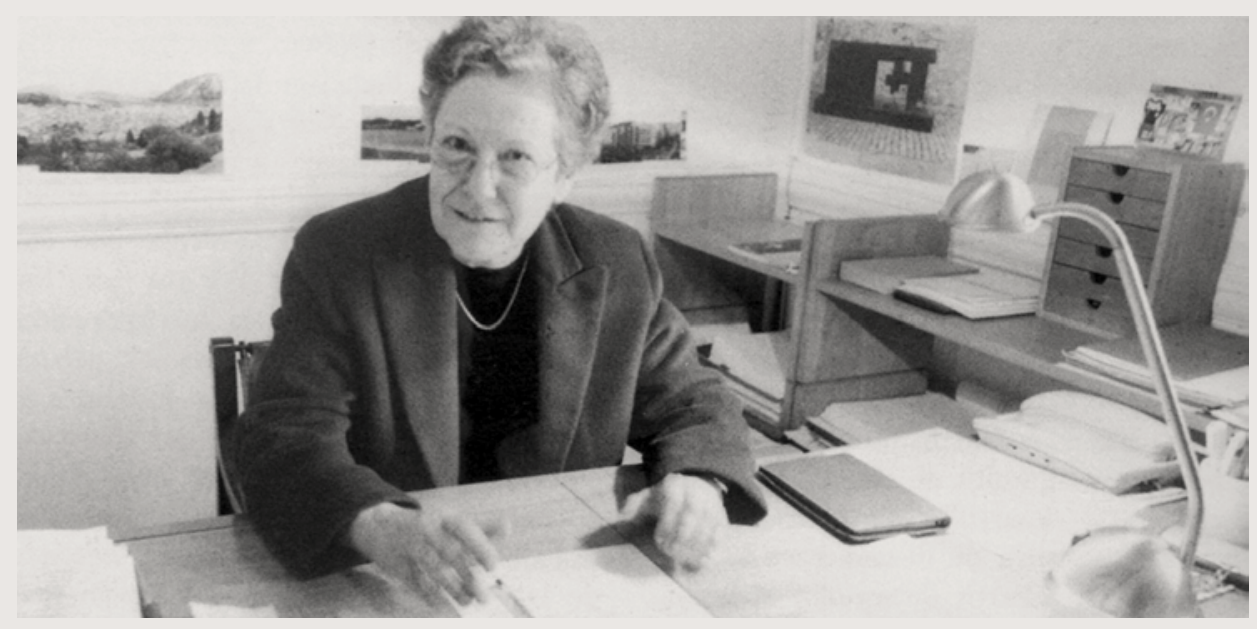

Sus espejos han reflejado lo mejor de la arquitectura nacional durante décadas, poniéndola al alcance de Chile y del mundo. Y la han reflejado, valga la analogía, como una profunda reflexión que muy probablemente ha incidido en el buen nivel de la arquitectura nacional y también en abrir las fronteras entre lo académico y lo profesional.

Gracias Montse...

Juan Ignacio Baixas F.

Director Escuela de Arquitectura, Pontificia Universidad Catolica de Chile.
Editorial que dice asi:

\author{
"Este periódico \\ que pretendemos mensual \\ quisiera documentar la conversación informal \\ el dibujo en la servilleta de papel \\ el pelambre \\ la observación precisa \\ el momento en que hacemos escuela. \\ La actividad de los profesores \\ tiene sus tribunas \\ sus ritos y su espontaneidad \\ los alumnos por su parte también \\ pero / un punto a medio camino \\ entre profesores $y$ alumnos \\ entre lo ritual y lo espontaneo \\ entre el yo hablando / siempre juicioso / profesor \\ $y$ \\ el yo hablando / en defensa propia / alumno \\ no existe / salvo en contadas ocasiones.
}

Cada cual desempeña su rol

cada cual sostiene su biombo ¿por qué?

en todo caso se presiente claramente que el biombo está de más

y que lo que realmente se necesita son espejos:

los alumnos son adultos

$y$ los profesores capaces

¿o no?

Veamos

De alguna manera lo que pretende este periódico con la colaboración directa de ustedes es apartar biombos y colocar espejos definir imágenes / enfatizar posiciones creo que hay disposición de todos profesores y alumnos para este empeño.

Espejos y no biombos Veamos."

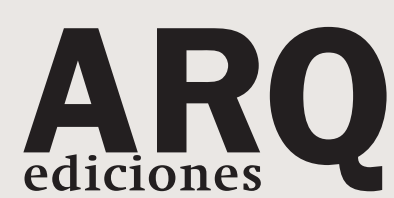

